\title{
Special Issue: The View from Late Antiquity
}

\section{Engaging the Political in the Religious Studies Classroom: Lessons from Studying Religion in Late Antiquity}

Authors' Note: The articles and contributions in this issue are designed to provide a framework for responsibly incorporating politics into the religious studies classroom. In the eventful months since this Issue has been in production, many new resources have emerged-on accessible pedagogy, anti-racist education, and citational ethics-that can help facilitate this incorporation. For a list of resources that the authors recommend, please see: https://www.engaging-politics-in-religiousstudies-classroom.com/.

We are living in times marked by rapid change, where long-held assumptions-about identity, history, politics, the environment, and religion, to name a few-are being questioned, upended, and reasserted by turns. Global markets and the internet have made the world seem both smaller and more vast, as people encounter one another across varying axes of difference and otherness, finding fellowship and antagonism in equal measure. Boundless ambition is valorized and habitually on display, while staggering inequality increases by leaps and bounds both globally and within individual countries.

Many of these same claims can be made about late antiquity, the period from approximately $250 \mathrm{CE}-800 \mathrm{CE}$ in the Mediterranean and Europe. What had once been termed the "dark ages" and dismissed as the wilderness years during which classical civilization unraveled and the Roman Empire collapsed has now been recognized as a vibrant, productive, and distinctive social and cultural era that saw not decline so much as transition, transformation, and an interplay of continuity and change fueled by the same types of dynamics we are seeing today. Late antiquity was marked by new forms of ambition as new means of acquiring power, wealth, and prestige emerged via military, imperial, or ecclesiastical service (among other avenues); it featured shifting concepts of government and theories of rule, of empire and commonwealth; it oversaw expanding understandings of divine power as monotheism spread; and, most spectacularly, it saw the diversification of influential voices, languages, and economies as the influence of Rome diminished. ${ }^{1}$ All of these shifts have had lasting (but long-unacknowledged) effects.

Given these legacies and the resonances between the era we study and our own, scholars of religion in late antiquity who teach in the United States find that the college classroom in 2020 presents a particular challenge. This challenge arises, primarily, from the various disconnects between what our research shows us and what the public often thinks of our time period, our material, and us. The general public often regards late antiquity (when they consider it at all) as either a monolith of benightedness or a chaos of collapse whose primary feature was the progressive disintegration of Roman "civilization." For other observers, the story of late antiquity is indeed one of growth, expansion, and development, but it is nonetheless a narrow and teleological story, centered on the timeline of how various orthodoxies-Christian, Jewish, and Muslim, primarily-emerged as "winners." From both of these perspectives, scholars of late antiquity would have little reason to engage in politics in the classroom or to teach classes with contemporary political relevance; on these views, our materials are settled, their interpretations largely fixed, and our role as teachers is to serve, apolitically, as guides to static and clearly visible historical tableaux.

\footnotetext{
1 For helpful introductions to late antiquity, see Johnson (2012), Bowersock, Brown, and Grabar (2001), Rousseau (2012), and Boin (2018). See also the classic Brown (1971, 1996), Cameron (1993a, 1993b), and Fowden (1993).

2 For a problematization of this, along with this model of historical winners and losers, see Gibbons and Fruchtman (2020).
} 
As scholars of the period, we know this not to be true. Our research, as scholars of history, philology, and religious studies, reveals a dynamic period of refreshing polyvocality, a time when concepts of "center" and "periphery" were in constant flux, an era that richly rewards explorations into concepts of gender, ethnicity, class, and ecology, and whose fullest possible portrayal in fact requires those very explorations. We know that the past is not unproblematically retrievable; that the historical record is ambiguous (as are, typically, the composition and transmission histories of the sources on which it is grounded) and its interpretation contested; and that even the categories that draw students to our classes-"religion," "late antiquity," "Christian," and "pagan," for example-are themselves on shaky definitional ground and, in the case of identity categories, may never have been as firm, fixed, or exclusive as their surviving proponents have made them out to be. All of this knowledge has contemporary political consequences, as it problematizes many of the narratives that we, as humans, tell ourselves about ourselves as we formulate our own political and politicized identities. Destabilizing the supposedly settled historical and interpretational foundations of these identities is a profoundly political activity.

This is undoubtedly even more the case when we are destabilizing the historical and interpretational foundations of supremacist ideologies-white supremacist, western supremacist, and Christian supremacist in particular. This is something that scholars who teach late ancient religion are confronted with regularly in the classroom and daily in public discourse: each of these ideologies depends upon misunderstandings of or ignorance of late antiquity. For example, the Christian supremacist who wants to argue that certain forms of Christianity "won out" because they were in some way "better" than alternative traditions will be, upon studying late antiquity, surprised to find the lines between traditions to be fuzzy, ambiguous, and sometimes simply nonexistent (more extensively discussed in Gibbons and Fruchtman [2020]). And those who would seek to ground triumphalist views of whiteness or western civilization in the classical period (like many of those noted by Zuckerberg [2018]) are stymied by the interpellation of late antique readers and curators into their historical fictions. That texts typically only survived from classical antiquity due to the copying choices of subsequent generations (rendering classical literature subject to late ancient selection bias) is not something that figures into the historical assessments of alt-right influencers who want to claim a connection to the legacies of Greece and Rome. Indeed, while the nineteenth-century poet Percy Bysshe Shelley claimed affinity with the ancient Greeks by noting that "our laws, our literature, our religion, our arts, have their roots in Greece" (1886 [1822]), our experience of those roots has been irrevocably shaped by late antiquity. To return to Bowersock, Brown, and Grabar:

It is, for instance, from late antiquity, and not from any earlier period of Roman history, that we have inherited the codifications of Roman law that are the root of the judicial systems of so many states in Europe and the Americas. The forms of Judaism associated with the emergence of the rabbinate and the codification of the Talmud emerged from late antique Roman Palestine and from the distinctive society of Sassanian Mesopotamia. The basic structures and dogmatic formulations of the Christian church, both in Latin Catholicism and in the many forms of Eastern Christianity, came from this time, as did the first, triumphant expression of the Muslim faith. Even our access to the earlier classics of the ancient world, in Latin and Greek, was made possible only through the copying activities of late antique Christians and their early medieval successors, locked in an endless, unresolved dialogue with their own pagan past. (2001, ix-x)

Any account of classical history that does not acknowledge the late ancient filter is inaccurate and, more than that, irresponsible.

And so teachers who deal with this material in our classrooms cannot be apolitical. One might suggest that the difference between politicizing and not politicizing our classrooms lies in what our learning objectives are. Is our goal merely to impart knowledge about late antiquity and hope that our students, on their own, will use it to problematize supremacist narratives? Or is our goal, baked into our classes and their learning objectives, to have our students realize that their conceptions of the present will have to be reconsidered in light of the late ancient past? ${ }^{3}$ But such a suggestion operates on the misguided assumption that not expressly engaging contemporary takeaways is an apolitical stance. Our classrooms (and public discourse) are already politicized, having been shaped by and dominated by these triumphalist narratives. Failing to explicitly undercut them is, in itself, a political act that bolsters the status quo and furthers the naturalization of ideas that we should, with attention to our material, be destroying.

To respond to this challenge, then, we must engage responsibly with politics in the classroom. But how? That is what this special issue seeks to explore. It is one of several fruits of a workshop, held in November 2017 (and described in Upson-Saia and Doerfler [2020]), in which scholars of late ancient religions gathered to collaboratively address what we felt to be a newly intensified need for intellectually and socially responsible approaches to engaging politics in our classrooms. The challenge described above had become more pronounced in the lead-up to the 2016 U.S. election, and the urgency only escalated in its aftermath, as it became increasingly acceptable in public discourse to weaponize identity categories and use them as rejection-enabling shorthand or,

3 See, for example, the discussion of (and subsequent dispute over) whether medievalists must explicitly identify themselves to their students as not being white supremacists (Kim 2018). 
worse, as buffers against acknowledging the humanity of those placed within those categories. Many of us felt compelled to do something to more effectively push against the widespread understanding of traditions and identities as discrete, timeless, and unchanging; additionally, we felt compelled to learn how we could best serve our students in this fraught political environment as we helped them build toward similar insights.

This special issue, then, seeks to help scholars of late antiquity (and others) rise to this challenge-to give scholars of religion in this period and in other pre-modern settings some additional tools with which to engage politics in the classroom (and encouragement as they embark on or continue the endeavor). We also hope to share with colleagues outside of this special area, in both religious studies and theology departments, some of the myriad ways that late ancient and pre-modern materials can be deployed to address politics in a variety of classrooms. The contributions in this issue are all by scholars of late ancient religion and make extensive use of late ancient materials, but the ideas and tactics here collected are broadly applicable even outside this area of specialization. Our hope is that we can support colleagues across the academy in incorporating politics responsibly into their classrooms in the future.

\section{Notes on Contributions and Commitments}

All of the contributions in this special issue are by scholars of religion in late antiquity either working in or trained in religious studies, even though not all of the examples they employ are late ancient and not all of their pieces are centered on content. The rationale behind using authorial specialization (rather than content) as our metric of inclusion is three-fold. First, it reflects the reality of our roles as instructors in the contemporary college classroom. Although we teach at a wide range of institutions-state flagships, small liberal arts colleges (SLACs), Ivies, and regional campuses of state systems-and although we include scholars with tenure, scholars on the tenure track, scholars teaching within the precariat, and graduate students, none of us is able to teach entirely within our area of specialization: we also teach service classes, surveys, and seminars with broad appeal; thus, religion in late antiquity is often only a fraction of the content we teach. Second, the decision to include pedagogues by virtue of their research expertise and not their choice of content is aspirational: we are seeking to claim our position as experts, to use what we have learned in our research and our training in every aspect of what we do, including politically-engaged pedagogy. Third, we wanted to be faithful to our experience in the classroom: we know that incorporating politics in the classroom is never solely about content, and that even if we were teaching entirely within late antiquity, we would need to consider things like civic engagement, positionality, and what guidelines to follow for establishing our own sets of best practices in the classroom. ${ }^{4}$ An additional benefit of this approach, we hope, is that this collection will appeal to a broader audience and help them make connections between our contributions and their own areas of expertise (pre-modern or otherwise).

As a final introductory note on our contributors, we want to identify two axes on which we are less diverse than we had intended or hoped to be. First, the majority of us are scholars of Judaism and Christianity in late antiquity. There are other traditions, most prominently Islam, whose scholars would certainly have enhanced the offerings here but are not well represented among our authors. Second, we are, for the most part, white. The perspectives of more scholars of color would also have benefited this volume, and we have fallen short on that front, as well. With these two particular shortcomings, we have replicated extant imbalances in the study of late antiquity. We feel it might be illuminating here to pause and examine the process that has culminated in those deficiencies.

Though the November 2017 workshop was broadly advertised, the only people who could easily attend were scholars already attending the AAR/SBL in Boston. Indeed, the Middle East Studies Association, where many scholars of early Islam (in particular) find their primary conversation partners, was running in Washington, D.C. at the very same time. Thus, already, participation was skewed toward scholars of Judaism and Christianity who had access to travel funding (or lived in the Boston area) and a schedule that allowed them to stay past the end of the Annual Meeting. ${ }^{5}$ After the workshop, when it became clear that publication might be a fruitful route for using, building on, and publicizing our collaborative findings, some scholars were actively disincentivized from joining the collaboration: many institutions still devalue or even penalize scholarship of teaching and learning in tenure portfolios, for example; in other cases, potential collaborators with minoritized identities and areas of study were discouraged by the threat of retaliation, the heavier workloads that often come with minority status, and even the "diversity fatigue" (Lam 2018) that almost always accompanies minoritization. Even the opportunity to focus our research on politically-engaged pedagogy was afforded to us by layer upon layer of privilege.

4 We also wanted to address ability status and Universal Design.

5 These circumstances also explain the centering of U.S. scholarship and the U.S. political context. 
The group of seven scholars who joined together to produce academic research on "Politics, Pedagogy, and the Profession" (the authors of the longer articles in this issue) reflected on this situation when we conceived our plans for the articles you see here; we resolved to do the work of "accomplices," which is to educate ourselves and other people of privilege instead of relying solely on

the exploited labor of minoritized and marginalized people. As part of this resolution, we agreed to deal directly with minoritization in all of our articles and to prioritize and use already-published works by scholars of color.

We also write with the hope that the new digital format of The Wabash Center Journal on Teaching will facilitate expansive and proliferating conversations by enabling easy navigation between and connection among pieces in separate issues, thus allowing sustained and ongoing trajectories of discussion on this topic. We invite and encourage scholars of religion in late antiquity who can offer different perspectives and ideas to join the conversation by publishing responses and addenda in this venue, or by joining the private Facebook group ${ }^{6}$ through which we are sharing resources and discussing classroom strategies.

Most importantly, however, the problem of representation in this issue reveals the work that still needs to be done at the undergraduate level to encourage people who are underrepresented in late ancient studies into the academic pipeline, to make the field itself more diverse. This means showing minoritized students that the material is relevant to their lives and interests, and that their questions, concerns, and insights about late ancient sources and the ways we study them are welcome and, indeed, salutary for the health of the field. And so we hope that this issue can help in this aim.

\section{Process and Products}

The articles in this issue developed via a fully collaborative process which has worked well to improve all of our individual thinking and (we hope) the final product (Upson-Saia and Doerfler [2020], Ronis and Proctor [2020], Gibbons and Fruchtman [2020], and Fruchtman and Park [2020]). The seven of us met via Skype (with myself, in the capacity of guest editor, acting as facilitator, rather than a leader or collector of materials), and together discussed what aspects of the problem needed the sustained attention of full-length research articles. We agreed that we needed some historical perspective on the question of engaging politics in the religious studies classroom, an exploration of positionality and how religious studies methodology can help us illuminate a richer account of identity politics, and a framework or set of guidelines to use when expanding one's pedagogy to explicitly incorporate the political into the classroom. We also conceived of an introductory essay that would frame the project and sketch out our reasons for embarking on it. We assigned these articles to teams of two to three people, with team leaders acting as facilitators and primary authors, always working collaboratively via team meetings over Skype and document sharing services (DropBox and GoogleDocs). Using a shared Google Drive folder to collect and categorize relevant research, some for individual articles and some for the whole group, ${ }^{7}$ we maintained consistent contact throughout the process. At various points, all seven of us would meet (again via Skype) to share our writings so far and gather comments and suggestions, and each of the articles bears the ghosts of many conversations beyond its margins.

The first article, "Politics and the Pedagogue of Late Antiquity" (Upson-Saia and Doerfler 2020), dives deeper into the necessity for pedagogues of pre-modern religion, particularly those who study late antiquity, to engage politics in the classroom in intellectually responsible ways. It describes the workshop which sparked the collaboration from which this special issue grew, outlines the understanding of politics that runs throughout the contributions, and notes the importance of collaboration for making our fields more inclusive.

The next article, "The Past, Present, and Religious Studies Future of Civic Engagement in American Higher Education" by Sara Ronis and Travis Proctor (2020), details the ways that civic engagement is fundamental to the stated work of the university, the humanities, and the project of religious studies. The article traces the historical connections between civic engagement and higher education in the American context to the present period, highlighting a consistency of focus on civic engagement across diverse university contexts even as educational priorities shift, before exploring the particular role of civic engagement in religious studies pedagogy. The authors contend that the integration of civic engagement in the late antique religion classroom enhances students' ability to understand complex concepts in late ancient religion and underscores the relevance of their study to students' lives. The article concludes by proposing three concrete strategies for incorporating civic engagement into the religious studies classroom:

\footnotetext{
6 You can find the Facebook group, "Politics, Pedagogy, and the Profession," at https://www.facebook.com/groups/760110884387955/.

7 Importantly, at Upson-Saia's urging we all read Killen and Gallagher (2013) prior to our initial discussion, so that we could have a solid understanding of what models of scholarship of teaching and learning in religious studies we would want to follow.
} 
cultivating naming practices, focusing pedagogical exercises on honing students' civic engagement skills, and, where practicable, engaging in community-based learning.

The theme of political discourse as both a vital aspect of religious studies and a pedagogical partner for the study of pre-modernity is continued in the third article. In their "Politics and Positionality in the Religious Studies Classroom," Kathleen Gibbons and Diane Shane Fruchtman (2020) suggest that examinations of positionality through the lens of religious studies methodologies provide necessary and salutary correctives to the ways that politics is assumed to operate in the classroom. The authors propose that examination of the ways in which relations of power inform imaginative representations of "the other" offers resources for critiquing binary and doctrinal conceptions of the political, including, for example, the notion of politics unfolding along a binary "liberal-conservative" spectrum. The article delineates and critiques different models for bringing positionality to the fore of the classroom, and provides readers with concrete examples for productively interrogating the role of power in knowledge production.

Implicit in these essays is the understanding of the classroom as an inescapably political zone. This claim, once accepted, requires instructors to adapt their pedagogy accordingly, recognizing that choices in the classroom will replicate, reinforce, or resist the political status quo. This is the starting point of the final article, "Accepting the Inevitability of Politics in the Classroom: A Proposal for How to Identify Best Practices in Effective and Inclusive Religious Studies Pedagogy” (Fruchtman and Park 2020). In it, Diane Shane Fruchtman and Chan Sok Park propose guiding principles ("classroom climate considerations") for discerning best practices in developing one's own religious studies pedagogy with attention to the presence of politics in the classroom. The article concludes with suggestions-structural, instructor-focused, and student-focused-that illustrate the types of strategies that can be employed within their proposed parameters.

The subsequent contributions to this issue-each Conversation, Design and Analysis, and Teaching Tactic-was solicited after these longer articles had coalesced: when we proposed the special issue to The Wabash Center Journal on Teaching, they graciously offered us the opportunity to expand and invite contributions from a wider group of colleagues studying late ancient religion, who could give examples of the types of pedagogical interventions and guiding principles we discuss in the articles. We solicited these with a general and open-ended call (to workshop participants and others in the field through listservs and social media), as well as with specific invitations to instructors we knew to be active in incorporating politics into their classrooms. While these individually authored pieces were not collaborative in the same way as the articles were, the seven original collaborators made themselves available as sounding boards to the new contributors as they turned their pieces from proposals to reality, in an attempt to further promote collaborative collegiality around this question of how scholars of religion in late antiquity can engage politics in the classroom.

\section{BIBLIOGRAPHY}

Boin, Douglas. 2018. A Social and Cultural History of Late Antiquity. Malden, MA: Blackwell.

Bowersock, Glen W., Peter Brown, and Oleg Grabar, eds. 2001. Interpreting Late Antiquity: Essays on the Postclassical World. Cambridge, MA: Harvard University Press.

Brown, Peter. 1971. The World of Late Antiquity: AD 150-750. New York, NY, W. W. Norton and Company.

Brown, Peter. 1996. The Rise of Western Christendom: Triumph and Diversity, A.D. 200-1000. Malden, MA: Blackwell.

Cameron, Averil. 1993a. The Later Roman Empire: AD 284-430. Cambridge, MA: Harvard University Press.

Cameron, Averil. 1993b. The Mediterranean World in Late Antiquity: AD 395-600. New York, NY: Routledge.

Fowden, Garth. 1993. Empire to Commonwealth: Consequences of Monotheism in Late Antiquity. Princeton, NJ: Princeton University Press. 
Fruchtman, Diane Shane, and Chan Sok Park. 2020. "Accepting the Inevitability of Politics in the Classroom: A Proposal for How to Identify Best Practices in Effective and Inclusive Religious Studies Pedagogy." The Wabash Center Journal on Teaching 1, no. 3: 57-72. https://doi.org/10.31046/wabashcenter.v1i3.567.

Gibbons, Kathleen, and Diane Shane Fruchtman. 2020. "Politics and Positionality in the Religious Studies Classroom." The Wabash Center Journal on Teaching 1, no. 3: 41-56. https://doi.org/10.31046/wabashcenter.v1i3.577.

Johnson, Scott Fitzgerald, ed. 2012. The Oxford Handbook of Late Antiquity. Oxford: Oxford University Press.

Killen, Patricia O'Connell, and Eugene V. Gallagher. 2013. "Sketching the Contours of the Scholarship of Teaching and Learning in Theology and Religion.” Teaching Theology \& Religion 16, no. 2: 107-124. https://doi.org/10.1111/ teth.12020.

Kim, Dorothy. 2018. “Medieval Studies Since Charlottesville.” Inside Higher Education, August 30. https://www.insidehighered.com/views/2018/08/30/scholar-describes-being-conditionally-accepted-medievalstudies-opinion.

Lam, Mariam. 2018. “Diversity Fatigue Is Real.” The Chronicle of Higher Education, September 28. https://www.chronicle.com/article/Diversity-Fatigue-Is-Real/244564.

Ronis, Sara, and Travis Proctor. 2020. "The Past, Present, and Religious Studies Future of Civic Engagement in American Higher Education.” The Wabash Center Journal on Teaching 1, no. 3: 23-40. https://doi.org/10.31046/wabashcenter.v1i3.574.

Rousseau, Philip, ed. 2012. A Companion to Late Antiquity. Malden, MA: Wiley-Blackwell.

Shelley, Percy Bysshe. 1886 [1822]. Hellas, a Lyrical Drama by Percy Bysshe Shelley: A Reprint of the Original Edition Published in 1822. London, UK: The Shelley Society.

Upson-Saia, Kristi, and Maria Doerfler. 2020. "Politics and the Pedagogue of Late Antiquity." The Wabash Center Journal on Teaching 1, no. 3: 9-22. https://doi.org/10.31046/wabashcenter.v1i3.1785.

Zuckerberg, Donna. 2019. Not All Dead White Men: Classics and Misogyny in the Digital Age. Cambridge, MA: Harvard University Press.

ABOUT THE AUTHOR

Diane Shane Fruchtman, Assistant Professor in the Religion Department at Rutgers University, is a scholar of Christian thought whose research explores rhetoric and the realities it helps construct, particularly in the realms of violence and martyrdom. She is currently working on a monograph, Surviving Martyrdom: Martyrdom Without Death in the Late Ancient Latin West and Beyond. 